\title{
Association between hematological profile and serum 25-hydroxyvitamin D levels and Fokl polymorphism in individuals with cystic fibrosis
}

\author{
Associação do perfil hematológico com os \\ valores séricos de 25-hidroxivitamina $D$ \\ e polimorfismo Fokl em indivíduos \\ com fibrose cística
}

Milena Luana Coelho de ASSIS1 (D) 0000-0002-8000-0806

Constantino Giovanni Braga CARTAXO2 (iD) 0000-0002-6763-6594

Maria José de Carvalho COSTA1 (iD) 0000-0001-5441-8654

Dayanna Joyce Marques QUEIROZ1 (D) 0000-0001-5989-3622

Darlene Carmati PERSUHN³ (D) 0000-0001-5291-5454

Maria da Conceição Rodrigues GONÇALVES1 (D) 0000-0001-7223-8470

\section{A B S T R A C T}

\section{Objective}

The present study aimed at investigating the association between hematological profile and serum 25-hydroxyvitamin D (25[OH]D) levels and Fokl polymorphism of the vitamin D receptor gene in individuals with Cystic Fibrosis.

1 Universidade Federal da Paraíba, Centro de Ciências da Saúde, Programa de Pós-Graduação em Ciências da Nutrição. Cidade Universitária, s/n., Castelo Branco, 58051-900, João Pessoa, PB, Brasil. Correspondência para/Correspondence to: MCR GONÇALVES. E-mail: <mariadaconceicaorgoncalves@gmail.com>.

2 Universidade Federal da Paraíba, Centro de Ciências Médicas, Departamento de Pediatria e Genética. João Pessoa, PB, Brasil.

3 Universidade Federal da Paraíba, Centro de Ciências Exatas e da Natureza, Programa de Pós-Graduação em Ciências da Nutrição. João Pessoa, PB, Brasil.

Article based on the master thesis of MLC ASSIS, entitled "Prevalência do Polimorfismo FOKI do Gene VDR em Pacientes Portadores de Fibrose Cística: Associação com Valores Hematológicos e 25-Hidroxivitamina D". Universidade Federal da Paraíba; 2017.

Como citar este artigo/How to cite this article

Assis MLC, Cartaxo CGB, Costa MJC, Queiroz DJM, Persuhn DC, Gonçalves MCR. Association between hematological profile and serum 25-hydroxyvitamin D levels and Fokl polymorphism in individuals with cystic fibrosis. Rev Nutr. 2018;31(2):211-20. http://dx.doi.org/10.1590/1678-98652018000200007 


\section{Methods}

A cross-sectional study that involved 18 men and women aged 0-25 years with Cystic Fibrosis. Socio-demographic information and the factors associated with sun exposure were obtained. Weight, height, and arm circumference were also measured. Blood sample was collected for the analysis of biochemical parameters (25[OH]D, parathyroid hormone, and calcium levels and blood count) and for the validation of the presence of Fokl polymorphism in the vitamin D receptor gene.

\section{Results}

Among the participants, 33.33\% $(n=6)$ had vitamin D deficiency $(19.60 \pm 6.180 \mathrm{ng} / \mathrm{mL})$, and $27.8 \%(n=5)$ presented with anemia and low weight for age. In terms of genotype, $5.6 \%(n=1)$ presented with the FF genotype, $72.3 \%(n=13)$ had the Ff genotype, and $22.2 \%(n=4)$ had the ff genotype. Serum $25(\mathrm{OH}) \mathrm{D}$ levels were associated with hemoglobin $(p=0.008)$ and hematocrit $(p=0.019)$ levels and leukocyte count $(p=0.0114)$. No association was observed between $25(\mathrm{OH}) \mathrm{D}$ levels and the genotypes (FF, Ff, and ff) $(p=0.2451)$. In addition, an association was observed between Fokl polymorphism and the total leukocyte count $(p=0.01)$.

\section{Conclusion}

An association was observed between serum 25(OH)D levels and hemoglobin and hematocrit levels and leukocyte count in individuals with Cystic Fibrosis. Moreover, Fokl polymorphism was associated with total leukocyte count.

Keywords: Cystic fibrosis. Hemoglobins. Polymorphism, genetic. Vitamin D.

\section{R E S U M O}

\section{Objetivo}

Esta pesquisa teve por objetivo investigar a associação do perfil hematológico com os valores séricos de 25-hidroxivitamina $D$ e polimorfismo Fokl do gene receptor da vitamina $D$ em indivíduos com fibrose cística, acompanhados em um centro de referência do Nordeste Brasileiro.

\section{Métodos}

Trata-se de estudo transversal, realizado com 18 indivíduos com fibrose cística, de ambos os sexos, com idade entre zero e 25 anos. Foram coletadas informações sociodemográficas e investigados fatores associados à exposição solar. Também foram aferidas medidas antropométricas de peso, estatura e circunferência do braço. O sangue foi coletado para análise dos parâmetros bioquímicos (25-hidroxivitamina D, paratormônio, cálcio e hemograma) e verificação da presença do polimorfismo Fokl do gene receptor da vitamina $D$.

\section{Resultados}

Da amostra total, 33,33\% ( $n=6)$ apresentaram insuficiência/deficiência de vitamina D (19.60 $\pm 6.180 \mathrm{ng} / \mathrm{ml})$, e $27,8 \%(n=5)$ acusaram anemia e baixo peso para a idade. No tocante aos genótipos, 5,6\% $(n=1)$ apresentaram genótipo $F F, 72,3 \%(n=13)$ apresentaram genótipo Ffe 22,2\% (n=4) apresentaram genótipo ff. Houve associação entre os valores séricos de 25-hidroxivitamina $D$ e os de hemoglobina $(p=0.008)$, hematócrito $(p=0.019)$ e leucócitos ( $p=0.0114$ ). Não houve associação entre os valores de 25-hidroxivitamina $D$ e os genótipos (FF, Ff e ff) $(p=0.2451)$. Além disso, houve associação entre o polimorfismo Fokl e a contagem total de leucócitos ( $p=0.01)$.

\section{Conclusão}

O presente estudo encontrou associação entre os valores séricos de 25-hidroxivitamina D e os de hemoglobina, hematócrito e leucócitos nos indivíduos analisados. Além disso, encontrou-se associação do polimorfismo Fokl com a contagem total de leucócitos.

Palavras-chave: Fibrose cística. Hemoglobinas. Polimorfismo genético. Vitamina D.

\section{INTRODUCTION}

Cystic Fibrosis (CF) is a fatal autosomal recessive disease that is more common in Caucasians and caused by mutations in the
CF Transmembrane Conductance Regulator (CFTR) gene. The dysfunction in this channel leads to changes in the viscosity, volume, and concentration of salt in the body fluids, leading to the formation of thick secretions, which prevent 
the hydration of the airways and create a favorable environment for bacterial colonization, chronic inflammation, and eventually respiratory insufficiency [1-3].

The incidence of the disease varies according to ethnicity, that is, from $1 / 1800$ to $1 / 5000$ live births in Caucasians in Europe, the United States, and Canada, 1/14000 in AfroAmericans, and $1 / 40000$ in Finns. This is a rare disease among Asians and Africans. In Brazil, the incidence is approximately $1 / 7000$. However, it is subjected to regional variations [1].

For more than 37 years, the median survival of these individuals increased from 10 years to 12 years, and one of the main contributing factors in the increase was the understanding of the role of nutrition in the general health state of these individuals [4].

Nutrition plays an important role in the treatment of CF because it influences the survival and quality of life of the patients. Approximately $90 \%$ of patients present with exocrine pancreatic insufficiency, resulting in poor digestion and absorption of nutrients, and consequently steatorrhea and poor stunted growth. Fat loss through feces carries the risk of liposoluble vitamin deficiency, including vitamin D. In addition, these patients have increased energy expenditure due to the nature of the disease and the frequency and severity of infections and chronic pulmonary inflammation. Thus, the importance of nutrition in these patients is reinforced $[1-3,5]$.

With regard to minerals, iron deficiency is frequent in patients with $\mathrm{CF}$ and is multifactorial [5]. However, in adults with CF, iron deficiency is mainly functional due to chronic inflammation [6]. In children with $C F$, anemia can be due to malnutrition or inadequate erythropoiesis or both [2].

Vitamin $D$ is more commonly associated with poor bone formation. However, its role in health is still being investigated, particularly in terms of extra-skeletal functions. Recently, vitamin $D$ has been associated with several diseases, including hypertension, diabetes Mellitus, cardiovascular diseases, cancer, and chronic obstructive pulmonary disease, and implicated in a wide range of biological mechanisms, including muscle strengthening, cell proliferation and differentiation, and regulation of the immune system. Its association with anemia has been suggested in recent years, indicating a role in the homeostasis of iron and erythropoiesis $[3,7,8]$. Vitamin $D$ insufficiency has been associated with a higher prevalence of anemia among different age groups, that is, from children to healthy adults and elderly patients [9].

The discovery that most of the body tissues and cells contain vitamin $D$ receptors and that several of these tissues have the enzymatic property to convert the primary form of vitamin $D$ in the circulation to its active form has provided new insights about the function of this steroid hormone [10]. In addition, the concentration of 1,25 -hydroxyvitamin $\mathrm{D}(1,25[\mathrm{OH}] \mathrm{D})$ is a hundred times greater in the bone marrow than in the plasma. The clinical consequences of its deficit have been a topic of interest due to the new insights about the biological functions of vitamin $D$, and the hypotheses that there is an association between vitamin $D$ and hemoglobin levels and that this phenomenon may be influenced by polymorphisms in the Vitamin D Receptor gene (VDR) have been reinforced $[11,12]$. Currently, these polymorphisms have been associated with renal insufficiency, diabetes, hypertension, and autoimmune diseases [13].

Studies have indicated the existence of several Single Nucleotide Polymorphisms (SNP) in the VDR gene. Several of these polymorphisms alter the activity of the VDR proteins [14], which include Apal, Bsml, and Taql (within exons 8 and 9) as well as Fokl (located in exon 2) [15].

Thus, this study aimed at assessing the association between the hematological profile and serum 25(OH)D and Fokl polymorphism of the VDR gene in individuals with CF who visited a referral center in northeastern Brazil. 


\section{METHODS}

\section{Characteristics of the participants and study design}

This cross-sectional observational study included a non-probabilistic convenience sample of 22 men and women aged 0-25 years who were diagnosed with CF. These patients were followed-up at the Pediatric Outpatient Clinic of Hospital Universitário Lauro Wanderley da Universidade da Paraíba (HULW-UFPB, Lauro Wanderley University Hospital - Federal University of Paraiba) in the city of João Pessoa, Paraiba. Informed consent was obtained from the patients or caregivers, and patients aged 12-18 years signed an assent term. Individuals who presented with biochemical alterations that indicate liver or renal insufficiencies and/or chronic diseases that alter vitamin D metabolism were excluded from the study.

Data were collected between May 2016 and September 2016. In terms of the seasons of the study region, the four seasons of the year were not well defined, since the region has the characteristics of summer throughout the year, with some months with more rainy or cloudy days and with temperatures ranging from $23^{\circ}$ to $34^{\circ} \mathrm{C}$.

The study was approved by the research ethics committee of the HULW-UFPB (CAAE $n^{\circ}$ 52248815.9.0000.5183). The study was in accordance with Resolution no 466/12 of the National Health Council/Ministry of Health.

Initially, all participants or guardians answered a questionnaire, which included personal data (name, date of birth, family income, and education level) as well as information on skin phototype, average time of exposure to the sun, use of pharmaceutical products, and clothing. The questionnaire was used by trained researchers.

Nutritional status was assessed using the Body Mass Index (BMI) for age and Arm Circumference $(A C)$. BMI was calculated by dividing weight in kilograms by height in meters squared. The Arm Circumference (AC) was measured utilizing a stretchable anthropometric tape measure. The measurement was made at the midpoint between the acromion and the olecranon [16]. BMI measurements were classified according to the World Health Organization (WHO) 2006 and 2007 [17] charts for patients aged less than 5 years. For the classification of patients older than 18 years, the values proposed by the WHO [18] were used. The percentile table proposed by Frisancho was used as a reference for the classification of $A C$ [19].

\section{Biochemical assessment}

Participants were instructed to fast for 12 hours. All analyses were performed in the clinical analysis laboratory at the HULW-UFPB in João Pessoa. Analysis of calcium levels and blood count was carried with the Wiener commercial kits using a CMD 800i analyzer (Wiener Lab Group, Argentina) or Sysmex XN1000 (Sysmex, Brazil), which was in accordance with the manufacturer's instructions. The recommended reference values by the manufacturer were used. Parathyroid Hormone (PTH) and 25(OH)D levels were determined by chemiluminescence using the Abbott Architect i2000 apparatus.

The serum concentration of $25(\mathrm{OH}) \mathrm{D}$ was classified based on the recommendation by the Endocrine Society. Serum concentrations between $20 \mathrm{ng} / \mathrm{mL}$ and $29 \mathrm{ng} / \mathrm{mL}(50-75 \mathrm{nmol} / \mathrm{L})$ were considered within normal limits, and those below $20 \mathrm{ng} / \mathrm{mL}$ (50nmol/L) were considered below the normal range [20]. The reference values stipulated for calcium were $8.8-11.0 \mathrm{mg} / \mathrm{dL}$, and those for PTH were $15.0-68.3 \mathrm{pg} / \mathrm{mL}$. The cut-off hemoglobin level that was used for the diagnosis of anemia was $12 \mathrm{ng} / \mathrm{dL}$.

\section{Identification of the VDR Fokl genotype}

DNA was extracted from $4 \mathrm{~mL}$ of whole blood obtained through venous puncture using 
sterile tubes containing $7.2 \mathrm{mg}$ of K3EDTA. The extraction of genomic DNA was performed according to a previously described methodology [21].

The genotypes were determined using PCR-RFLP. The primers used were 5'-AGCTGGC CCTGGCACTGACTCTGCTCT-3' (sense) and 5-A TGGAAACACCTTGCTTCTTCTCCCTC-3' (antisense), and amplification was carried out under the following conditions: initial denaturation at $94^{\circ} \mathrm{C}$ for 5 minutes, 35 cycles of denaturation (30 seconds at $94^{\circ} \mathrm{C}$ ), annealing (30 seconds at $60^{\circ} \mathrm{C}$ ), and extension $\left(30\right.$ seconds at $72^{\circ} \mathrm{C}$ ) with an extra final extension step of 10 minutes. The 265-pb product was digested with Fokl, which recognizes and cleaves the polymorphic allele $f$, generating two fragments (196bp and 69bp), whereas the ancestral allele $\mathrm{F}$ remains at $265 \mathrm{pb}$. The genotypes were analyzed via electrophoresis using $10 \%$ polyacrylamide gel and staining with $0.5 \%$ silver nitrate [22].

\section{Statistical analysis}

Data were expressed in percentage, mean, and standard deviation. All data were tested for normality and homogeneity using the Shapiro-Wilk test and Levene's test, respectively. Differences between the groups were tested using the independent Student's t-test or MannWhitney $U$ test. Bivariate analysis was carried out to evaluate the statistical associations between the variables and serum 25-(OH)D levels in the insufficient/deficient and sufficient groups using the Spearman chi-squared test and Pearson's correlation test. The Spearman chi-squared test was used to verify the influence of the dominant allele (F). All statistical analyses were performed using Instat and SPSS version 21 (Statistical Package for the Social Sciences, released 2012 IBM SPSS statistics for windows, version 21, Armonk, New York, IBM Corp.) using a significance level of $5 \%$.

\section{RES U L T S}

Among the 22 participants, 18 were finally included in the analysis due to the loss of $18.2 \%(n=4)$ of the sample due to problems related to data collection or refusal to participate in the research. No biochemical changes that indicated hepatic or renal insufficiency were observed in the participants. In addition, the presence of chronic diseases that alter the metabolism of vitamin D was not observed.

The sample included individuals with an average age of $10.61 \pm 6.57$ years, of which $55.60 \%(n=10)$ were men and $44.40 \%(n=8)$ were women (Table 1). Table 2 shows the mean serum $25(\mathrm{OH}) \mathrm{D}$ levels of the general population, which are within normal range (mean: $34.63 \pm 13.768 \mathrm{ng} / \mathrm{dL})$, and $33.33 \%(n=6)$ had a serum $25-(\mathrm{OH}) \mathrm{D}$ level of $30 \mathrm{ng} / \mathrm{dL}$. In relation to the genotypes, $5.6 \%(n=1)$ presented with the FF genotype, $72.30 \%(n=13)$ presented with the Ff genotype, and $22.20 \%(n=4)$ presented with ff genotype. In addition, the prevalence rate for anemia and low weight for age was $27.80 \%$ $(n=5)$. Data are not presented.

A lower level of serum hemoglobin $(p=0.008)$ and hematocrit $(p=0.019)$ was observed in the deficient group, and these values were positively correlated with the levels of $25(\mathrm{OH}) \mathrm{D}(0.592 \mathrm{ng} / \mathrm{dL}$ and $0.512 \mathrm{ng} / \mathrm{dL}$, respectively). In addition, these individuals had higher leukocyte count ( $p=0.0114$ ) (Table 2).

Based on the analysis, no association was observed between the genotypes (FF, Ff, and ff) and 25-(OH)D levels $(p=0.2451)$ (Table 3). An association was observed between the genotype FF/Ff and total leukocyte count ( $p=0.01$ ) (Table 4).

\section{DISCUSSION}

Studies on the association between hematological profile and serum 25-(OH)D levels and the Fokl polymorphism of the VDR gene in individuals with CF. Thus, this is the first study 
Table 1. Characteristics of the participants and association between serum 25-hydroxyvitamin $D$ level and the sociodemographic data of individuals with cystic fibrosis. João Pessoa (PB), Brazil, 2016).

\begin{tabular}{|c|c|c|c|c|c|c|c|}
\hline \multirow[t]{2}{*}{ Variables } & \multicolumn{2}{|c|}{ Participants $(n=18)$} & \multicolumn{2}{|c|}{$\begin{array}{l}\text { Individuals with normal } \\
25(\mathrm{OH}) D^{*} \text { levels }(n=12)\end{array}$} & \multicolumn{2}{|c|}{$\begin{array}{c}\text { Individuals with low } \\
25(\mathrm{OH}) D^{* *} \text { levels }(n=6)\end{array}$} & \\
\hline & Prevalence & $\mathrm{n}$ & Prevalence & $n$ & Prevalence & $\mathrm{n}$ & \\
\hline \multicolumn{8}{|l|}{ Gender } \\
\hline Male & $55.6 \%$ & 10 & $75 \%$ & 9 & $16.67 \%$ & 1 & \\
\hline Female & $44.4 \%$ & 8 & $25 \%$ & 3 & $83.33 \%$ & 5 & \\
\hline \multicolumn{8}{|l|}{ Level of education } \\
\hline Illiterate & - & - & - & - & - & - & \\
\hline 1st degree & $44.45 \%$ & 8 & $58.33 \%$ & 7 & $16.67 \%$ & 1 & \\
\hline 2nd degree & $44.45 \%$ & 8 & $41.67 \%$ & 5 & $50 \%$ & 3 & \\
\hline Graduate & $11.10 \%$ & 2 & - & - & $33.33 \%$ & 2 & \\
\hline Post-graduate & - & - & - & - & - & - & \\
\hline \multicolumn{8}{|l|}{ Family income } \\
\hline $1-5$ minimum wages & $88.88 \%$ & 16 & $100 \%$ & 12 & $66.66 \%$ & 4 & \\
\hline 5-10 minimum wages & $5.56 \%$ & 1 & - & - & $16.67 \%$ & 1 & \\
\hline$>10$ minimum wages & $5.56 \%$ & 1 & - & - & $16.67 \%$ & 1 & \\
\hline \multicolumn{8}{|l|}{ Skin color } \\
\hline Very pale & $16.67 \%$ & 3 & - & - & $50 \%$ & 3 & \\
\hline Fair & $22.22 \%$ & 4 & $16.67 \%$ & 2 & $33.33 \%$ & 2 & \\
\hline Less fair & $16.67 \%$ & 3 & $16.67 \%$ & 2 & $16.67 \%$ & 1 & \\
\hline Light brown & $16.67 \%$ & 3 & $25 \%$ & 3 & - & - & \\
\hline Dark brown & $22.22 \%$ & 4 & $33.33 \%$ & 4 & - & - & \\
\hline \multirow[t]{2}{*}{ Black } & $5.55 \%$ & 1 & $8.33 \%$ & 1 & - & - & \\
\hline & \multicolumn{2}{|c|}{ Mean SD } & Mean & SD & \multicolumn{2}{|c|}{ Mean SD } & płvalue \\
\hline Age (years) & \multicolumn{2}{|c|}{$10.61 \pm 6.57$} & \multicolumn{2}{|c|}{$11.03 \pm 4.400$} & \multicolumn{2}{|c|}{$9.66 \pm 10.13$} & 0.6797 \\
\hline $\mathrm{BMI}\left(\mathrm{kg} / \mathrm{m}^{2}\right)$ & \multicolumn{2}{|c|}{$15.10 \pm 2.13$} & \multicolumn{2}{|c|}{$15.38 \pm 2.541$} & \multicolumn{2}{|c|}{$14.63 \pm 0.93$} & 0.52 \\
\hline Exposure to sunlight (minutes) & \multicolumn{2}{|c|}{$20 \pm 19.92$} & \multicolumn{2}{|c|}{$24.54 \pm 23.71$} & \multicolumn{2}{|c|}{$11.66 \pm 4.02$} & 0.11 \\
\hline
\end{tabular}

Note: ${ }^{*} 25(\mathrm{OH}) \mathrm{D} \geq 75 \mathrm{nmoL} / \mathrm{L}$ (30ng/mL). ${ }^{* *} 25(\mathrm{OH}) \mathrm{D}<75 \mathrm{nmoL} / \mathrm{L}$ (30ng/mL). ${ }^{\dagger}{ }^{* * *}$ Values between the groups, according to the independent Student $t$-test.

Data are expressed as mean and Standard Deviation (SD); 25(OH)D: 25-hydroxyvitamin D; BMI: Body Mass Index; PTH: Parathyroid Hormone.

that evaluated this association. In addition, because CF is a rare disease, a sample of 18 patients is representative, and the results found are relevant.

Based on the data obtained in the present study, an association was observed between serum 25-(OH)D levels and hemoglobin $(p=0.008)$ and hematocrit $(p=0.019)$ levels and total leukocyte count $(p=0.0114)$. Individuals with 25-(OH)D deficiency had lower hemoglobin and hematocrit levels and increased total leukocyte count than those with normal hemoglobin and hematocrit levels and total leukocyte count. In addition, no correlation was observed between the genotypes ( $F F, F F$, and $\mathrm{ff}$ ) and the serum $25-(\mathrm{OH}) \mathrm{D}$ levels $(p=0.2451)$.

The results of the present study were in accordance with those of previous studies [23]. When examining the interrelationships between iron and vitamin $D$ and the hormones in pregnant adolescents, Thomas et al. [24] have observed that maternal 25-(OH)D level was positively associated with maternal hemoglobin level during the start of gestation as well as during delivery $(p<0.01$ 
Table 2. Biochemical variables according to serum 25 -hydroxyvitamin D levels in individuals with cystic fibrosis. João Pessoa (PB), Brazil 2016.

\begin{tabular}{|c|c|c|c|c|c|c|c|}
\hline \multirow[t]{2}{*}{ Variables } & \multicolumn{2}{|c|}{$\begin{array}{c}\text { General } \\
(n=18)\end{array}$} & $\begin{array}{l}\text { Individuals with } \\
\text { normal } 25(\mathrm{OH}) \mathrm{D}^{*} \\
\text { levels }(\mathrm{n}=12)\end{array}$ & \multirow[t]{2}{*}{$95 \% \mathrm{Cl}$} & $\begin{array}{l}\text { Individuals with } \\
\text { low } 25(\mathrm{OH}) \mathrm{D}^{* *} \\
\text { levels }(\mathrm{n}=6)\end{array}$ & \multirow[t]{2}{*}{$95 \% \mathrm{Cl}$} & \multirow{2}{*}{$\begin{array}{c}\begin{array}{c}\text { Student } \\
t \text {-test }\end{array} \\
p^{t_{\text {value }}}\end{array}$} \\
\hline & Mean & SD & Mean SD & & Mean SD & & \\
\hline 25(OH)D ${ }^{1}$ levels & \multicolumn{2}{|c|}{$34.63 \pm 13.768$} & $42.15 \pm 9.53$ & $36.09-48.02$ & $19.60 \pm 6.18$ & $13.11-26.08$ & $<0.001$ \\
\hline PTH level & \multicolumn{2}{|c|}{$41.1 \pm 17.717$} & $42.38 \pm 18.25$ & $30.78-53.98$ & $38.53 \pm 17.96$ & $19.68-57.38$ & 0.6772 \\
\hline Calcium² level & \multicolumn{2}{|c|}{9,960} & 10.020 & $9.87-10.29$ & 9.800 & $8.59-10.34$ & 0.2161 \\
\hline HMG ${ }^{1}$ level & \multicolumn{2}{|c|}{$12.91 \pm 1.602$} & $13.56 \pm 1.26$ & $12.76-14.36$ & $11.53 \pm 1.44$ & $10.06-13.09$ & 0.008 \\
\hline HMT $^{1}$ level & \multicolumn{2}{|c|}{$39.09 \pm 4.700$} & $40.85 \pm 3.84$ & $38.40-43.29$ & $35.56 \pm 4.49$ & $30.84-40.28$ & 0.019 \\
\hline Leukocyte ${ }^{1}$ count & \multicolumn{2}{|c|}{$10,286.11 \pm 3,847.8$} & $8,790.8 \pm 2,556.2$ & $7,166.7-10,415$ & $13,277 \pm 4,457.1$ & 8,598.4-17,955 & 0.0114 \\
\hline
\end{tabular}

Note: Data are expressed as mean and Standard Deviation (SD). ${ }^{*} 25(\mathrm{OH}) \mathrm{D} \geq 75 \mathrm{nmoL} / \mathrm{L}(30 \mathrm{ng} / \mathrm{mL}){ }^{* *} 25(\mathrm{OH}) \mathrm{D}<75 \mathrm{nmoL} / \mathrm{L}(30 \mathrm{ng} / \mathrm{mL}) .{ }^{1 * * *}$ Parametric data according to normality test, comparison between the groups according to the independent Student t-test. ${ }^{{ }^{* * *}}{ }^{\text {Non-parametric data, }}$ comparison between groups according to the Mann-Whitney test presented as medians.

25(OH)D: 25-hydroxyvitamin D; PTH: Parathyroid Hormone; HMG: Hemoglobin; HMT: Hematocrit.

Table 3. Association between genotypes and serum 25-hydroxyvitamin D levels in individuals with cystic fibrosis. João Pessoa (PB), Brazil, 2016.

\begin{tabular}{|c|c|c|c|c|c|c|c|c|c|}
\hline \multirow{3}{*}{ Genotypes } & \multicolumn{9}{|c|}{ 25(OH)D levels } \\
\hline & \multicolumn{2}{|c|}{$\begin{array}{l}\text { Sufficient } \\
\qquad(n=12)\end{array}$} & \multicolumn{2}{|c|}{$\begin{array}{l}\text { Insufficient/deficient }{ }^{* *} \\
\qquad(\mathrm{n}=6)\end{array}$} & \multicolumn{2}{|c|}{$\begin{array}{l}\text { Number of participants } \\
\qquad(18)\end{array}$} & \multirow[t]{2}{*}{ OR } & \multirow[t]{2}{*}{$95 \% \mathrm{Cl}$} & \multirow[t]{2}{*}{$p$} \\
\hline & $n$ & $\%$ & $n$ & $\%$ & $\mathrm{n}$ & $\%$ & & & \\
\hline FF/FF genotype & 8 & 44 & 6 & 33 & 14 & 78 & 0.1453 & $0.0065-3.212$ & 0.2451 \\
\hline ff genotype & 4 & 22 & & & 4 & 22 & & & \\
\hline
\end{tabular}

Note: *25(OH)D $\geq 75 \mathrm{nmoL} / \mathrm{L}(30 \mathrm{ng} / \mathrm{mL}) ;{ }^{* *} 25(\mathrm{OH}) \mathrm{D}<75 \mathrm{nmoL} / \mathrm{L}(30 \mathrm{ng} / \mathrm{mL})$.

OR: Odds Ratio; $95 \%$ Cl: 95\% Confidence Interval; p: p value according to the chi-squared test. 25(OH)D: 25-hydroxyvitamin D.

Table 4. Biochemical variables in accordance with the allelic distribution of the VDR FokI polymorphism in individuals with cystic fibrosis. João Pessoa (PB), Brazil, 2016.

\begin{tabular}{|c|c|c|c|c|c|}
\hline \multirow[t]{2}{*}{ Variables } & $\begin{array}{l}\text { FF/Ff genotype } \\
\qquad(n=14)\end{array}$ & \multirow[t]{2}{*}{$95 \% \mathrm{Cl}$} & $\begin{array}{l}\text { ff genotype } \\
\qquad(\mathrm{n}=4)\end{array}$ & \multirow[t]{2}{*}{$95 \% \mathrm{Cl}$} & \multirow{2}{*}{$\begin{array}{c}\begin{array}{c}\text { Student } \\
t \text {-test }\end{array} \\
p^{t} \text { value }\end{array}$} \\
\hline & Mean SD & & Mean SD & & \\
\hline 25(OH)D level (mg/dL) & $32.35 \pm 14.02$ & $24.26-40.45$ & $42.60 \pm 10.62$ & $25.71-59.49$ & 0.19 \\
\hline PTH ${ }^{1}$ level & $37.60 \pm 13.10$ & $30.03-45.12$ & $53.35 \pm 27.80$ & $8.99-97.72$ & 0.11 \\
\hline Calcium² level & 9.925 & $9.42-10.13$ & 10.16 & $9.55-10.83$ & $0.27^{2}$ \\
\hline Hemoglobin ${ }^{\mathbf{1}}$ level & $12.59 \pm 1.30$ & $11.82-13.33$ & $14.05 \pm 2.21$ & $10.53-17.57$ & 0.10 \\
\hline Hematocrit ${ }^{1}$ level & $38.676 \pm 4.11$ & $36.16-40.91$ & $41.00 \pm 6.75$ & $30.24-51.75$ & 0.37 \\
\hline
\end{tabular}

Note: Data are expressed as mean and Standard Deviation (SD).

${ }^{*} 25(\mathrm{OH}) \mathrm{D} \geq 75 \mathrm{nmoL} / \mathrm{L}(30 \mathrm{ng} / \mathrm{mL}) .{ }^{* *} 25(\mathrm{OH}) \mathrm{D}<75 \mathrm{nmoL} / \mathrm{L}(30 \mathrm{ng} / \mathrm{mL})$.

${ }^{1 * * *}$ Parametric data according to normality test, comparison between the groups according to the independent Student $t$-test. ${ }^{2 * * *}$ Non-parametric data, comparison between the groups according to the Mann-Whitney test presented as medians.

25(OH)D: 25-hydroxyvitamin D; PTH: Parathyroid Hormone. 
for both). In addition, maternal 25-(OH)D level was inversely associated with erythropoietin level during the onset of gestation $(p<0.05)$ and during delivery $(p<0.001)$.

Recently, Silva et al. [25] investigated the association between hematological profile and serum 25-(OH)D levels and the Bsml polymorphism of the VDR gene in noninstitutionalized elderly patients, thus showing that vitamin D deficiency is associated with low hemoglobin levels. The influence of nutritional status on anemia was assessed in this group, and no association was observed. Thus, this result was in accordance with that of previous studies showing that serum vitamin D levels is associated with hemoglobin levels.

In recent years, the associations between vitamin $\mathrm{D}$ and multiple chronic and degenerative diseases have been a topic of interest. These effects have been attributed mainly to the immunomodulatory and anti-inflammatory activity of vitamin D. The cells involved in these processes express the VDR gene and can produce and respond to its active form [26].

When assessing the association between serum 25-(OH)D levels and the biomarkers of oxidative stress, inflammation, and endothelial activation in obese children, researchers found insufficient serum 25-(OH)D levels (<20ng/ $\mathrm{mL}$ ) in $5 \%$ of individuals in the control group and in $30 \%$ of obese children. In addition, in obese children with vitamin D insufficiency, the concentrations of inflammatory markers were substantially higher [27].

Studies have shown that polymorphisms of the VDR gene affect the activity of its encoding protein and, consequently, the metabolic effects mediated by vitamin D. The Fokl polymorphism has been associated with increased susceptibility to gastric, prostate, liver, and breast cancer [2832]. It has also been associated with bone mass and the components of metabolic syndrome $[33,14]$.

Bhanushali et al. [34] have found a correlation between serum 25(OH)D levels $(p<0.05)$ and Taql but not with Fokl $(p>0.05)$ in healthy individuals in India.

On the other hand, in contrast to the results of a previous study mentioned above, Mackawy \& Badawi [14] have investigated the role of vitamin D in chronic inflammation and insulin resistance in Egyptians with Type 2 Diabetes (T2DM) and those with or without Metabolic Syndrome (METS). Moreover, they have found out that Fokl polymorphism is associated with serum 25(OH)D levels in individuals with T2DM and those with or without SM.

Previous studies on the association between the VDR Fokl polymorphism and inflammatory conditions in individuals have not been carried out. However, in the present study, results showed an increased prevalence of inflammatory diseases in individuals with the Fokl polymorphism, as reflected in the increase in total leukocyte count.

Moreover, only one polymorphism of the VDR gene was analyzed. Thus, other studies must be conducted to investigate the influence of other polymorphisms on the hematological profile and the metabolism of $25(\mathrm{OH}) \mathrm{D}$ in this population. In addition, as this is a crosssectional study, a causal relationship between Fokl polymorphism and total leukocyte count or serum $25(\mathrm{OH}) \mathrm{D}$ levels and hemoglobin and hematocrit levels and total leukocyte count cannot be established.

Although this study provided relevant data, it has some limitations. First, its sample size was reduced. Nevertheless, this study first evaluated the proposed associations, suggesting that it is reproducible in samples with larger sample sizes of patients with CF.

\section{CONCLUSION}

Results showed that vitamin D plays a role in regulating the immune response. In the present study, 25-(OH)D insufficiency was associated with hemoglobin and hematocrit 
levels and total leukocyte count in individuals with CF. In addition, an association was observed between the Fokl polymorphism and total leukocyte count.

\section{CONTRIBUTORS}

MLC ASSIS: Conception and design of the study, data acquisition, analysis and interpretation of data, drafting of the article; CGB CARTAXO: Conception and design of the study, analysis and interpretation of data, drafting of the article, review and approval of the final version of the article for submission; MJC COSTA: Conception and design of the study, analysis and interpretation of data, drafting of the article, review and approval of the final version of the article for submission; DJM QUEIROZ: Data acquisition, analysis and interpretation of data, review and approval of the final version of the article for submission; DC PERSUHN: Conception and design of the study, analysis and interpretation of data, drafting of the article, review and approval of the final version of the article for submission; MCR GONÇALVES: Conception and design of the study, analysis and interpretation of data, drafting of the article, review and approval of the final version of the article for submission.

\section{REFERENCES}

1. Haack A, Aragão GG, Novaes MR. Pathophysiology of cystic fibrosis and drugs used in associated digestive tract diseases. World J Gastroenterol. 2013;19(46):8552-61. http://dx.doi.org/10.3748/ wjg.v19.i46.8552

2. Woestenenk JW, Castelijns SJAM, Van der Ent CK, Houwen RHJ. Dietary intake in children and adolescents with cystic fibrosis. Clin Nutr. 2014;33(3):528-32. https://dx.doi.org/10.1016/j.clnu. 2013.07.011

3. Sexauer WP, Hadeh A, Ohman-Strickland PA, Zanni RL, Varlotta L, Holsclaw D, et al. Vitamin D deficiency is associated with pulmonary dysfunction in cystic fibrosis. J Cyst Fibros. 2015;14(4):497-506. http://dx.doi.org/10.1016/j. jcf.2014.12.006

4. Engelen MPKJ, Schroder R, Van der Hoorn K, Deutz NEP, Com G. Use of body mass index percentile to identify fat-free mass depletion in children with cystic fibrosis. Clin Nutr. 2012;31(6):927-33. http://dx.doi.org/10.1016/j.clnu.2012.04.012
5. Delgado AFD, Cardoso AL, Zamberlan P. Nutrologia básica e avançada. Barueri: Manole; 2010.

6. Uijterschout L, Nuijsink M, Hendriks D, Vos R, Brus F. Iron deficiency occurs frequently in children with cystic fibrosis. Pediatr Pulmonol. 2014;49(5):45862. http://dx.doi.org/10.1002/ppul.22857

7. Smith EM, Tangpricha V. Vitamin D and anemia: Insights into an emerging association. Curr Opin Endocrinol Diabetes Obes. 2015;22(6):432-38. http://dx.doi.org/10.1097/MED.000000000000 0199

8. Sim JJ, Lac PT, Liu ILA, Meguerditchian SO, Kumar VA, Kujubu DA, et al. Vitamin D deficiency and anemia: A cross-sectional study. Ann Hematol. 2010;89(5):447-52. http://dx. doi.org/10.1007/s0027 7-009-0850-3

9. Thomas CE, Guillet R, Queenan RA, Cooper EM, Kent TR, Pressman, et al. Vitamin D status is inversely associated with anemia and serum erythropoietin during pregnancy. Am J Clin Nutr. 2015;102(5):1088-95. http://dx.doi.org/10.3945/ ajcn.115.116756

10. Cabral MA, Borges CN, Maia JMC, Aires CAM, Bandeira F. Prevalence of vitamin D deficiency during the summer and its relationship with sun exposure and skin phototype in elderly men living in the tropics. Clin Interv Aging. 2013;8:1347-51. http://dx.doi.org/10.2147/CIA.S47058

11. Sezer $S$, Tutal E, Bilgic A, Ozdemir FN, Haberal $M$. Possible influence of vitamin $D$ receptor gene polymorphisms on recombinant human erythropoietin requirements in dialysis patients. Transplant Proc. 2007;39(1):40-4. http://dx.doi. org/10.1016/j.transproceed.2006.10.214

12. Amato M, Pacini S, Aterini S, Punzi T, Gulisano M, Ruggiero M. Iron indices and vitamin $D$ receptor polymorphisms in hemodialysis patients. Adv Chronic Kidney Dis. 2008;15(2):186-90. http://dx. doi.org/10.1053/j.ackd.2008.01.013

13. Perlstein TS, Pande R, Berliner N, Vanasse GJ. Prevalence of 25-hydroxyvitamin $D$ deficiency in subgroups of elderly persons with anemia: Association with anemia of inflammation. Blood. 2011;117(10):2800-6. http://dx. doi.org/10.1182/ blood-2010-09-309708

14. MacKawy AMH, Badawi MEH. Association of vitamin $D$ and vitamin $D$ receptor gene polymorphisms with chronic inflammation, insulin resistance and metabolic syndrome components in type 2 diabetic Egyptian patients. Meta Gene. 2014;2:540-56.

15. Schuch NJ, Garcia VC, Vívolo SR, Martini LA. Relationship between vitamin $D$ receptor gene polymorphisms and the components of metabolic syndrome. Nutr J. 2013;12(96):1-7. http://dx.doi. org/10.1186/1475-2891-12-96 
16. Cuppari L, Schor N. Guia de nutrição: nutrição clínica no adulto. Barueri: Manole; 2002.

17. Ministério da Saúde (Brasil). Secretaria de Atenção à Saúde. Departamento de Atenção Básica. Orientações para a coleta e análise de dados antropométricos em serviços de saúde: Norma Técnica do Sistema de Vigilância Alimentar e Nutricional - SISVAN. Brasília: Ministério da Saúde; 2011 [acesso $2018 \mathrm{abr}$ 13]. Disponível em: http://189.28.128.100/dab/docs/portaldab/ publicacoes/orientacoes_coleta_analise_dados_ antropometricos.pdf

18. World Health Organization. Physical status: The use and interpretation of anthropometry. Geneva: WHO; 1995 [cited 2018 Apr 13]. Available from: http://apps.who.int/iris/bitstream/handle/10665/3 7003/WHO_TRS_854.pdf; jsessionid=5ADBB0B7 8B37ACB361472CC2458313CO? sequence=

19. Frisancho AR. Anthropometric standards for the assessment of growth and nutritional status. Ann Arbor: University of Michigan Press; 1990.

20. Holick MF, Binkley NC, Bischoff-Ferrari HA, Gordon CM, Hanley DA, Heaney RP, et al. Evaluation, treatment, and prevention of vitamin $D$ deficiency: An Endocrine Society clinical practice guideline. J Clin Endocrinol Metab. 2011;96(7):1911-30. http://dx.doi.org/10.1210/jc.2011-0385

21. Miller AS, Dykes DD, Polesky HF. A simple salting out procedure for extracting DNA from human nucleated cells. Nucleic Acids Res. 1988;16(3):1215.

22. Chiu KC, Chuang LM, Yoon C. The vitamin D receptor polymorphism in the translation initiation codon is a risk factor for insulin resistance in glucose tolerant Caucasians. BMC Med Genet. 2001;2(1):2. http://dx.doi.org/10.1186/1471-235 $0-2-2$

23. Sakka ASE, Imam SS, Amer HA, Moustafa AS. Vitamin D deficiency and low hemoglobin level as risk factors for severity of acute lower respiratory tract infections in Egyptian children: A case-control study. Gaz Egypt Paediatr Assoc. 2014;62(1):1-7.

24. Thomas CE, Guillet R, Queenan RA, Cooper EM, Kent TR, Pressman EK, et al. Vitamin D status is inversely associated with anemia and serum erythropoietin during pregnancy. Am J Clin Nutr. 2015;102(2):1088-95.

25. Silva AS, Issa CTM, Queiroz DJM, Persuhn DC, Araújo EPS, Gonçalves MCR. Association of hematology profile with serum 25-hydroxy vitamin $D$ and Bsml polimorphism in community-dwelling older adults. Rev Nutr. 2016;29(5):655-64. http:// dx.doi.org/10.159011678-98652016000500004

26. Angel B, Lera L, Sánchez H, Oyarzún A, Albala C. Fokl polymorphism in vitamin $D$ receptor gene: Differential expression of TNF $\alpha$ in peripheral mononuclear cells of type 2 diabetic subjects. Meta Gene. 2016;7:1-6.

27. Codoñer-Franch $P$, Tavarez-Alonso $S$, SimoJorda R, Laporta-Martın P, Carratala-Calvo A, Alonso-Iglesias E. Vitamin D status is linked to biomarkers of oxidative stress, inflammation, and endothelial activation in obese children. J Pediatr. 2012;161(5):848-54

28. Xu H, Li S, Qiu JQ, Gao XL, Zhang P, Yang YX. The VDR gene FokI polymorphism and ovarian cancer risk. Tumour Biol. 2013;34(6):3309-16. http://dx. doi.org/10.1007/s13277-013-0826-8

29. Cong L, Wang W, Liu Qi, Du J. Fokl polymorphism of the vitamin $D$ receptor ene is associated with susceptibility to gastric cancer: A case-control study. Tohoku J Exp Med. 2015;236(3):219-24. http://dx.doi.org/10.1620/tjem.236.219

30. Falleti E, Bitetto D, Fabris C, Cussigh A, Fontanini $E$, Fornasiere $E$, et al. Vitamin $D$ receptor gene polymorphisms and hepatocellular carcinoma in alcoholic cirrhosis. World J Gastroenterol. 2010;16(24):3016-24. http://dx.doi.org/10.3748/ wjg.v16.i24.3016

31. McKay JD, McCullough ML, Ziegler RG, Kraft $P$, Saltzman BS, Riboli $E$, et al. Vitamin D receptor polymorphisms and breast cancer risk: Results from the National Cancer Institute Breast and Prostate Cancer Cohort Consortium. Cancer Epidemiol Biomarkers Prev. 2009;18(1):297-305. http://dx. doi.org/10.3748/wjg.v16.i24.301610.1158/105 5-9 965.EPI-08-0539

32. Li H, Stampfer MJ, Hollis JB, Mucci LA, Gaziano JM, Hunter D, et al. A prospective study of plasma vitamin D metabolites, vitamin D receptor polymorphisms, and prostate cancer. PLoS Med. 2007;4(3):e103. http://dx.doi.org/10.1371/journal. pmed.0040103

33. Falchetti A, Sferrazza C, Cepollaro C, Gozzini A, Del Monte F, Masi L, et al. Fokl polymorphism of the vitamin $D$ receptor gene correlates with parameters of bone mass and turnover in a female population of the Italian Island of Lampedusa. Calcif Tissue Int. 2007;80(1):15-20. http://dx.doi. org/10.1007/s00223-005-0295-1

34. Bhanushali A, Lajpal N, Kulkarni S, Chavan S, Bagadi S, Das B. Frequency of fokl and taql polymorphism of vitamin $D$ receptor gene in Indian population and its association with 25-hydroxyvitamin D levels. Indian J Hum Genet. 2009;15(3):108-13. 